\title{
The Use of Visualization in Teaching and Learning Process for Developing Critical Thinking of Students
}

Kyvete Shatri

University of Prishtina

Kastriot Buza

University of Prishtina

\begin{abstract}
Many researches has been conducted for the need to increase critical thinking of students (in (different fields, (also many researches has been done on the importance and the role of critical thinking for students achievements. In this context this requires a critical approach. To achieve this should be used effective teaching methods that develop critical thinking and also facilitate and enhance the learning of students and their performance in general, making them able to solving problems in their fields. A visualization approach increase communication, increase critical thinking and provides analytical approach to various problems. Therefore, this research is aimed to investigate visualization for the purpose of examining its role in developing critical thinking. In order to achieve this it was made an experiment for the use of visualization and from this experimentation are extracted the results of the effect of using the visualization for the aspect of developing and increasing critical thinking. The results which are taken from this research highlight the positive effect that the use of visualization in teaching and learning process has in developing the critical thinking of students and their overall performance. The results also shows that the visualization motivates students to learn, making them more cooperative and developing their skills for critical approach.
\end{abstract}

Keywords: visualization, critical thinking, teaching, learning, student performance

\section{Introduction}

For educators (teaching learners the content of respective academic disciplines is not difficult, but teaching learners how to think effectively about subject matter is often not (so easy and is often not achieved. Learners are not born with the power to think critically, nor do they develop this ability naturally. It is a learned ability, the development of which needs to be facilitated (Makina, 2010). Critical thinking is a mode of thinking about any subject content or problem in which the thinker improves the quality of his or her thinking by skillfully taking charge of the structures inherent in thinking and imposing intellectual standards upon them (Scriven \& Paul, 2005). Critical thinking emphasizes the skills of analysis, teaches learners how to understand, follow or create a logical argument, work out the answer, eliminate the incorrect paths and focus on the correct one (Harris, 2002). Given the importance of critical thinking for students learning, teachers and students should look for the ways and components that they can use to develop critical thinking of the students. In this context, should exploited technological developments. The developing of technology has influenced (the ways of teaching and learning. Its integration in these two processes has contributed in the transformation of teaching and learning, from the traditional way to the with pupil in the center. Technology components of information and communication have offered new ways as for teaching also for learning and one of them is the offering of the visualized way of teaching and learning (Shatri, 2015). Visual teaching and learning is essential in today's education for developing critical thinking. Since critical thinking should be prominent in the learning of students, any strategy used to develop and encourage it is considered useful. Tools for visualization usually are used to grow the level of learning and to develop critical thinking and also they promoting some different styles of learning which supporting the attitude of students. In this paper will be presented the effects of use of visualization in teaching and learning process for ( developing the critical thinking of students in the course of (" Object Oriented Programming" in University of Prishtina. 


\section{Visualization}

Visualization through visual imagery has been an effective way to communicate both abstract and concrete ideas since the dawn of humanity. According to Presmeg :" visualization is an aid to understanding, and one can therefore speak about visualizing a concept or a problem. To visualize a problem means to understand the problem in terms of a visual (mental) image - hence the visualization process is one that involves visual imagery, with or without a diagram, as an essential part of the method of solution (Presmeg 1992). In another side, we cannot ignore the (fact that today's students are generation that are visualized to learn. So, these students should offer knowledge throw the visual way, with strategy of active learning (Gangwer, 2015). We can consider visualization (as the tool which can helps teachers to make instructional decisions about how to teach, the content and the nature of tasks. Visualization, also offers a method of seeing the unseen and we are encouraged and should aspire to 'see' not only what comes 'within sight', but also what we are unable to see (Arcavi, 2003). Relationship between graphics and a type of information, increases learning and creates opportunities for application of what that is taught (Janitor \& al, 2010).

\section{Critical Thinking}

Critical Thinking is the intellectually disciplined process of actively and skillfully conceptualizing, applying, analyzing, synthesizing, and/or evaluating information gathered from, or generated by, observation, experience, reflection, reasoning, or communication, as a guide to belief and action (Jessop, 2002). According to Van den Berg: "in an increasingly complex and specialised society, it is imperative that individuals think critically" (Van den Berg, 2004). A teacher who fosters critical thinking fosters reflectivity and visualisation in learners by asking questions that stimulate thinking, which is essential to the construction of knowledge. The integration of visual teaching have a positive influence in the motivation students to learn, grow the level of learning and fosters (cirtical thinking. Ultimately through the use of visualisation students learn how to think critically in a complex situation (Brumfield, 2005).

\section{Methodology of Research}

To conduct this research are used (mixed methods: quantitative and qualitative ones. These methods consist on qualitative and quantitative analysis of the effect of use of the visualisation in the teaching (and learning process for developing critical thinking. Also it has been reviewed a relevant literature. The data have been taken from narrative reports of interviewed students, even statistics reports and questionnaires themselves.

The survey was conducted with 100 students from the Faculty of Electrical and Computer Engineering at the University of Pristina, who took part in two lectures. In the first lecture which was developed without the use of visualisation (have taken part 50 students (and in the second with the use of visualisation also have taken part 50 students. The first group would serve for us as a control group for second group. To accomplish the research there was developed two test one pre-test and one (test after lecture. Students from two groups have taken part in pre-test and test after lecture. The pre-test was developed to measure the general knowledge of the course content which are developed before the holding the test. While after the lecture test it was developed to measure student achievement for the content developed in that lecture. To realize the separation of students in groups (is taken as (a criteria the average grade, in order to have homogeneous groups in terms of average grade. So both groups have a similar average with a distinction in value of 0 . 18. Also was designed a questionnaire, which is the main instrument through which had been collected the opinions from students who have taken part in lecture developed with the use of visualisation. Students in this survey answered in these questions using an average from 5-points. Points in scale were the labelled "Fully agree ", "agree", "neutral", "disagree" and "strongly disagree". Finally, there were used ethical processes throughout the process of research and respected general rules in relation to the respondents.

\section{Data Analysis and Discussion of Results}

After processing the data obtained completed by respondents, in two tests from two groups, the compared the average points of tests for two groups are in the following tables:

\begin{tabular}{|l|l|l|l|l|}
\hline \multicolumn{4}{|l|}{ Table 1. The results of pre-test } \\
\hline $\begin{array}{l}\text { Group of students who will take part in lecture developed } \\
\text { (without v isualisation }\end{array}$ & $\begin{array}{l}\text { Group of students who will take part in lecture developed (with } \\
\text { visualisation }\end{array}$ \\
\hline Rank of & Number of & Rank of points & Number of & $\%$ \\
\hline
\end{tabular}




\begin{tabular}{|l|l|l|l|l|l|}
\hline points & students & & & students & \\
\hline $0-50$ & 10 & $20 \%$ & $0-50$ & 11 & $22 \%$ \\
\hline $51-70$ & 25 & $50 \%$ & $51-70$ & 26 & $52 \%$ \\
\hline $71-100$ & 15 & $30 \%$ & $71-100$ & 13 & $26 \%$ \\
\hline
\end{tabular}

\begin{tabular}{|c|c|c|c|c|c|}
\hline \multicolumn{3}{|c|}{$\begin{array}{l}\text { Group of students who will take part in lecture developed } \\
\text { (w ithout visualisation }\end{array}$} & \multicolumn{3}{|c|}{$\begin{array}{l}\text { Group of students w ho will take part in lecture developed (with } \\
\text { visualisation }\end{array}$} \\
\hline $\begin{array}{l}\text { Rank of } \\
\text { points }\end{array}$ & $\begin{array}{l}\text { Number of } \\
\text { students }\end{array}$ & $\%$ & Rank of points & $\begin{array}{l}\text { Number of } \\
\text { students }\end{array}$ & $\%$ \\
\hline $0-50$ & 14 & $28 \%$ & $0-50$ & 5 & $10 \%$ \\
\hline $51-70$ & 26 & $52 \%$ & $51-70$ & 30 & $60 \%$ \\
\hline $71-100$ & 10 & $20 \%$ & $71-100$ & 15 & $30 \%$ \\
\hline
\end{tabular}

(From the table we can see that the pre-test results obtained are more or less similar for both groups.

From the table wecan see that the results of after the lecture test for group of students which have taken part in lecture developed with visualisation they are better. The number of students with points in rank of points 0-50 is more less than number of students from the other group for the same rank of points, which are 14 students. This results tell us for the positive effect that have the use of visualisation in the teaching and learning process during the lectures. In this case the positive effect of visualisation was in developing critical thinking because the content which was developed during the lecture, to be (understood (needed a critical approach. The content that was developed in the lecture had concerned with the polymorphisms.

To get the opinion of students for the impact of the integration of visualisation during the teaching and learning process in developing their critical thinking, visualisation form of teaching would be compared with the traditional way of teaching (by using white or black tables). Students who have taken part in lecture developed with the use of visualization they answered the questions of the questionnaire. The gained results from the questionnaire filled in by students are presented on the following table.

\begin{tabular}{|c|c|c|}
\hline Effect & Visualisation & Whiteboard \\
\hline $\begin{array}{l}\text { It makes the teaching contend and distribute material through teaching } \\
\text { easier and more understandable }\end{array}$ & $85 \%$ & $15 \%$ \\
\hline $\begin{array}{l}\text { It enables discussion and testing theoretical problems encouraging } \\
\text { discussion and raising critical thinking }\end{array}$ & $92 \%$ & $8 \%$ \\
\hline Increase student's interest to take part in (classroom discussions & $75 \%$ & $25 \%$ \\
\hline $\begin{array}{l}\text { It offers the possibility to analyzeand draw conclusions on the material } \\
\text { ex amined }\end{array}$ & $95 \%$ & $5 \%$ \\
\hline $\begin{array}{l}\text { It makes the distributed material during teaching lessons easier and } \\
\text { more understandable }\end{array}$ & $90 \%$ & $10 \%$ \\
\hline It increases creativity & $98 \%$ & $2 \%$ \\
\hline $\begin{array}{l}\text { Increase the students 'possibility to judge in solving of problems which } \\
\text { are discussed in the classroom }\end{array}$ & $90 \%$ & $10 \%$ \\
\hline
\end{tabular}

This (obtained results has highlighted the positive impact that comes from the use of visualization as teaching and learning form. As we can see the $92 \%$ of students agree that the use of visualisation enables discussion and testing theoretical problems encouraging discussion and raising critical thinking.

\section{Conculsion}

From the results of this research is highlighted that the use of visualization as a teaching and learning form in the process of teaching and learning have a positive influence in increasing and developing the critical thinking of students. Visualisation is a very important component of understanding, and critical thinking determines the quality of the understanding. Without critical thinking, which is self-directed, self-corrective thinking the learning as a process (is difficult, as it relies on the 
memorization of knowledge. The interactive approach (enables students with different learning styles to comprehend theoretical constructs and apply them in a grounded practice.

\section{References}

[1] Arcavi A 2003. The role of visual representations in the learning of mathematics. Educational Studies in Mathematics, 52:215-241

[2] Brumfield, R. 2005, September 6). Computer simulation is 'making history'. eSchool New online: Where K-12 Education and Technology Meet. Retrieved November 13, 2016 at http://www. eschoolnews. com/news/PFshowstory. cfm?ArticlelD=5862

[3] Gangwer, T. 2015). Shifting To Visual Teaching, International Conference of creativity, Thinking \& Education, April 18-20, 2015 at the University of St. Thomas in Minnesota, p. 4.

[4] Harris R 2002. Creative thinking techniques. Retrieved from http://www. virtualsalt. com/crebook2. $\mathrm{htm}$ on 20 November 2007

[5] Janitor, Josef et al. 2010), visual learning tools for teaching and learning computer networks, 6th international conference on Networking and services

[6] Jessop, J. L. P. 2002). Expanding our students' brainpower: idea generation and critical thinking skills. IEEE Antennas and Propagation Magazine, 44 (6), 140-144.

[7] Makina. A, (2010), The role of visualization in developing critical thinking in mathematics, Perspectives in Education, Volume 28 (1), March 2010

[8] Presmeg NC 1992. Prototypes, metaphors, metonymies and imaginative rationality in high school mathematics. Educational Studies in Mathematics, 23:595-610

[9] Scriven M \& Paul R 2005. The critical thinking community. Retrieved from: http://www. Critical thinking. org. about CT/define critical thinking. cfm on 15 September 2016.

[10] Shatri, K. 2015), Visual teaching and learning in the fields of engineering, Academic Journal of Business, Administration, Law and Social Sciences Vol. 1 No. 3, IIPCCL Publishing, Tirana-Albania

[11] Van den Berg G 2004. The use of assessment in the development of higher-order thinking skills. Africa Education Review, 1:279-294 